\title{
PENERAPAN MODEL PEMBELAJARAN KOOPERATIF TIPE JIGSAW PADA KONSEP SISTEM PENCERNAAN MAKANAN MANUSIA TERHADAP KETRAMPILAN BERFIKIR KRITIS DAN SIKAP SISWA DI SMA NEGERI 1 SAKTI KABUPATEN PIDIE
}

\author{
Fadliyani1, Zufahmi2 \\ Program Studi Biologi \\ Fakultas Keguruan dan Ilmu Pendidikan Universitas Jabal Ghafur \\ fadliyani@gmail.com zufahmibio@gmail.com
}

\begin{abstract}
ABSTRAK
Penelitian tentang "Penerapan Model Pembelajaran Kooperatif Tipe Jigsaw Pada Konsep SistemPencernaan Makanan Manusia Terhadap Ketrampilan Berfikir Kritis dan Sikap Siswa di SMA Negeri 1Sakti Kabupaten Pidie". Penelitian ini bertujuan untuk mengetahui perbedaan ketrampilan berfikir kritisdan sikap siswa yang diajarkan dengan menggunakan model pembelajaran kooperatif Jigsaw dengan model pembelajaran konvensional. Metode yang digunakan dalam penelitian ini adalah metode eksperimen dengan desain penelitian pretest-postest control group design. Instrumen yang digunakan dalam penelitian ini adalah tes objektif berupa tes pilihan ganda. Pengumpulan data dilakukan dengan mencari N-Gain dan membandingkan N-Gain kelas eksperimen dengan N-Gain kelas kontrol. Data dianalisis dengan menggunakan uji-t independen sample t-test. Hasil analisis dengan menggunakan Uji T (t-test) Independent sample T-test, diperoleh bahwa nilai thit $(12,13)$ sedangkan nilai ttabel $(\alpha=$ $0,05)$ yaitu $(1,645)$, jadi dapat disimpulkan bahwa thit. \ৈtabel pada $(\alpha=0,05)$, maka Ha diterima, artinya terdapat perbedaan hasil belajar pada siswa antara kelas eksperimen dengan kelas kontrol.
\end{abstract}

Kata kunci:Jigsaw, Berfikir Kritis, Pencernaan Makanan

\section{PENDAHULUAN}

Pendidikan di Indonesia memiliki mutu dan kualitas yang berbeda jika dibandingkan dengan negara-negara maju. Kondisi ini dapat dilihat dari rata-rata nilai ujian nasional (UN) yang masih rendah. Zamroni (2000), mengatakan bahwa selama tiga dasawarsa ini perkembangan dunia pendidikan di Indonesia secara kuantitatif sangat pesat, ditandai dengan peningkatan jumlah siswa yang sekolah. Namun perkembangan tersebut belum diikuti oleh peningkatan kualitas yang diindikasikan dengan belum mampunya dunia pendidikan memenuhi kebutuhan dan tantangan nasional dan global (Sidi, 2001).

Pendidikan yang berhasil adalah pendidikan yang dapat menghasilkan suatu peserta didik yang berdaya saing tinggi dan peserta didik yang berkualitas dan kreatif. Proses pembelajaran pada saat ini memerlukan sebuah strategi belajar (2000) menyatakan bahwa inti dari proses pembelajaran adalah suatu pengaturan lingkungan, sehingga di dalamnya siswa dapat saling berinteraksi. Suatu model pembelajaran pada hakikatnya adalah suatu perencanaan pola mengajar, yang dapat digunakan oleh guru dalam proses pembelajaran di kelas untuk membantu siswa mencapai tujuan pembelajaran sehingga dapat memperoleh hasil belajar yang lebih baik. Perubahan hasil belajar dapat ditandai dengan perubahan kemampuan berfikir dan tingkat penguasaan terhadap materi pelajaran.

Dalam mengkondisikan lingkungan belajar yang baik dan untuk mempengaruhi siswa sehingga proses kegiatan belajar mengajar dapat berjalan secara maksimal, maka diperlukan suatu model pembelajaran yang inovatif. Pembelajaran kooperatif tipe jigsaw merupakan salah satu model pembelajaran inovatif yang dapat membawa siswa pada suasana belajar yang lebih aktif, karena pembelajaran jigsaw menggabungkan kegiatan membaca, menulis, mendengarkan dan berbicara. Hal ini sangat memberikan kesempatan bagi peserta didik untuk mengolah informasi dan kemudian mengkomunikasikannya sehingga dapat meningkatkan hasil belajar dan kemampuan berfikir kritis pada siswa.

Mengajar baru yang lebih menekankan pada partisipasi siswa (student oriented). Amali Telah banyak dilakukan penelitian tentang penerapan model pembelajaran kooperatif tipe jigsaw, diantaranya penelitian yang dilakukan 
oleh Saputra (2011), tentang studi komparasi antara pembelajaran kooperatif jigsaw dengan metode ceramah bervariasi menunjukkan tingkat ketuntasan belajar kelas dengan model jigsaw sebesar $87,56 \%$ sedangkan pada kelas kontrol sebesar 64,44\%.

Berdasarkan penelitian yang telah dilakukan dengan menggunakan model pembelajaran Jigsaw memberikan hasil yang positif pada prestasi belajar siswa. Penelitian ini dilakukan dengan sintaks atau tahapan pembelajaran yang berbeda dengan penelitian yang telah dilakukan sebelumnya. Dalam penelitian ini dilakukan modifikasi dari penelitian-penelitian sebelumnya pada tahap proses pembelajaran, yaitu tahap pengantar, kuis dan tahap pemantapan untuk meningkatkan interaksi, pemahaman konsep dan kemampuan berfikir kritis pada siswa. Tujuan penelitian ini adalah untuk mengetahui kemampuan berfikir kritis dan sikap siswa dengan penerapan model pembelajaran kooperatif tipe Jigsaw pada konsep system pencernaan makanan.

\section{KAJIAN LITERATUR DANHIPOTESIS \\ Kajian Literatur}

Susetyo (2011) mengatakan bahwa pendidikan formal merupakan suatu sistem pendidikan yang kompleks, karena dalam penyelenggaraannya memerlukan banyak komponen, seperti waktu, tenaga, perangkat pembelajaran, dan kerja sama berbagai pihak. Model pembelajaran merupakan kerangka konseptual yang melukiskan prosedur sistematik dalam mengorganisasikan proses pendidikan untuk mencapai tujuan pembelajaran dan berfungsi sebagai pedoman bagi perancang pengajaran dan para guru dalam merencanakan dan melaksanakan aktivitas belajar mengajar.

Pembelajaran kooperatif adalah salah satu bentuk pembelajaran yang berdasarkan paham konstruktivis. Pembelajaran kooperatif merupakan model belajar dengan sejumlah siswa sebagai anggota kelompok kecil yang tingkat kemampuannya berbeda. Dalam menyelesaikan tugas kelompoknya, setiap siswa anggota kelompok harus saling bekerja sama dan saling membantu untuk memahami materi pelajaran. Dalam pembelajaran kooperatif, belajar dikatakan belum selesai jika salah satu teman dalam kelompok belum menguasai materi pelajaran.
Ibrahim, (2000) mengatakan bahwa unsurunsur dasar pembelajaran kooperatif adalah sebagai berikut:

1. Siswa dalam kelompoknya haruslah beranggapan bahwa mereka sehidup sepenanggungan bersama.

2. Siswa bertanggung jawab atas segala sesuatu di dalam kelompoknya, seperti milik mereka sendiri.

3. Siswa haruslah melihat bahwa semua anggota di dalam kelompoknya memiliki tujuan yang sama.

4. Siswa harus membagi tugas dan tanggung jawab yang sama diantara anggota kelompoknya.

5. Siswa akan dikenakan evaluasi atau diberikan hadiah/penghargaan yang juga akan dikenakan untuk semua anggota kelompok.

6. Siswa berbagi kepemimpinan dan mereka membutuhkan keterampilan untuk belajar bersama selama proses belajarnya.

7. Siswa akan diminta mempertanggungjawabkan secara individual materi yang ditangani dalam kelompok kooperatif.

Arends (2001) mengungkapkan bahwa model pembelajaran kooperatif unggul dalam membantu siswa untuk memahami konsepkonsep, juga membantu siswa menumbuhkan kemampuan kerja sama, berfikir kritis dan mengembangkan sikap sosial siswa. Salah satu model pembelajaran kooperatif yang digunakan dalam penelitian ini adalah model kooperatif tipe jigsaw.

Model pembelajaran kooperatif tipe jigsaw didesain untuk meningkatkan rasa tanggung jawab siswa terhadap pelajarannya sendiri dan juga pembelajaran orang lain. Siswa tidak hanya mempelajari materi yang diberikan, tetapi mereka juga harus siap memberikan dan mengajarkan materi tersebut pada anggota kelompoknya yang lain. Dengan demikian, siswa saling tergantung satu dengan yang lain dan harus bekerja sama secara kooperatif untuk mempelajari materi yang ditugaskan, Lie (2008). Selanjutnya Slavin (2008) juga berpendapat bahwa pembelajaran kooperatif menggalakkan siswa berinteraksi secara aktif dan positif dalam diskusi kelompok.

Prianto dalam Wina Sanjaya (2009) mengemukakan langkah-langkah dalam pelaksanaan pembelajaran kooperatif jigsaw adalah sebagai berikut: 
1. Pembentukan kelompok asal. Siswa ditempatkan dalam kelompok beranggotakan 4-6 siswa, dan menerima sebagian informasi dari satu paket informasi yang harus dibahas dalam kelompok. 2. Setiap anggota kelompok asal mempelajari sub materi pelajaran yang akan menjadi keahliannya, kemudian masing-masing siswa mengerjakan tugas secara individu.

2. Pembentukan kelompok ahli. Ketua kelompok asal membagi tugas kepada masing-masing anggotanya untuk menjadi ahli dalam sub materi pelajaran. Masingmasing ahli yang sama dari kelompok yang berlainan bergabung membentuk kelompok baru yang disebut kelompok ahli.

3. Diskusi kelompok ahli. Anggota kelompok mengerjakan tugas-tugas dan saling berdiskusi tentang masalah- masalah yang menjadi tanggung jawabnya. Setiap anggota kelompok ahli belajar materi pelajaran sampai mencapai taraf merasa yakin untuk menyampaikan dan memecahkan persoalan yang menyangkut submateri pelajaran yang menjadi tanggung jawabnya.

4. Diskusi kelompok asal. Siswa anggota kelompok ahli kembali ke kelompok asal masing-masing. Setiap anggota kelompok asal menjelaskan dan menjawab pertanyaan submateri yang menjadi keahliannya kepada anggota kelompok asal yang lainnya. Kegiatan ini berlangsung secara bergilir sampai seluruh anggota kelompok asal telah mendapat giliran.

5. Diskusi kelas. Guru memfasilitasi kegiatan diskusi kelas dan menjelaskan tentang konsep-konsep penting yang menjadi bahan perdebatan dalam diskusi kelompok ahli, guru berusaha memperbaiki kesalahan konsep pada siswa.

6. Pemberian kuis. Kuis dikerjakan secara individu, nilai yang diperoleh masingmasing anggota kelompok asal dijumlahkan untuk memperoleh nilai kelompok.

7. Pemberian penghargaan kelompok.Kelompok yang memperoleh nilai tertinggi diberikan penghargaan berupa hadiah atau bonus nilai.
Berkaitan dengan penerapan model pembelajaran kooperatif tipe jigsaw, telah dilakukan beberapa penelitian diantaranya, penelitian yang dilakukan oleh Mawaddah (2011), hasil penelitiannya adalah penerapan pembelajaran problem solving dipadu kooperatif jigsaw pada mata pelajaran biologi ternyata hasil belajar siswa 71,00 lebih tinggi dibandingkan dengan kelas kontrol 61,92 di MTsN Model Palu.

Sulastri (2009), mengembangkan perangkat pembelajaran kooperatif jigsaw dalam pembelajaran biologi di SMP 2

Cimalaka, menunjukkan sudah memenuhi ketuntasan belajar dengan prosentase ketuntasan belajar sebesar $89,74 \%$.

Pendi (2002), melakukan penerapkan model pembelajaran kooperatif tipe jigsaw dalam pembelajaran mata kuliah Fisika Dasar II pokok bahasan arus listrik dan rangkaian arus listrik searah menunjukkan bahwa, secara umum kemampuan dosen dalam mengelola pembelajaran kooperatif tipe jigsaw adalah baik. Dosen mampu melatih keterampilan kooperatifdan mengoperasikan perangkat pembelajaran yang hampir sesuai dengan alokasi waktu yang tersedia, serta membuat mahasiswa antusias dalam mengikuti proses pembelajaran. Mahasiswa pada umumnya mengatakan senang dan merupakan hal yang baru terutama tentang keterampilan kooperatif. Mahasiswa berminat untuk mengikuti pembelajaran selanjutnya dengan model kooperatif tipe jigsaw.

$$
\text { Budiningarti (1998), }
$$

yang mengembangkan perangkat pembelajaran kooperatif tipe jigsaw pada proses pembelajaran Fisika di SMU. Hasilnya menunjukkan siswa pada kelas guru model dan kelas guru mitra, mengalami peningkatan pengetahuan untuk tes hasil belajar kognitif dan psikomotor. Handayani dan Sapir (2009) melakukan penelitian dengan menggunakan model yang sama. Hasil penelitian menunjukkan bahwa, hasil belajar yang diamati terdiri dari tiga aspek, yaitu kognitif, afektif dan psikomotorik. Secara keseluruhan hasil belajar siswa kelas XI IPS 1 SMA Negeri 2

Malang dapat ditingkatkan melalui pembelajaran berbasis masalah (Problem- Based Learning) dan pembelajaran kooperatif (Cooperative Learning) tipe Jigsaw. Hal ini dapat dilihat bahwa ketiga aspek dalam hasil belajar mengalami peningkatan.

\section{PENGEMBANGAN HIPOTESIS}

Jurnal Sains Riset | Volume VIII Nomor I 
Hipotesis dalam penelitian ini adalah terdapat perbedaan kemampuan berfikir kritis dan sikap pada siswa yang diajarkan dengan penerapan model pembelajaran tipe jigsaw dan pembelajaran konvensional. Jika t-hitung $\leq$ ttabel, maka Ha ditolak, dan Ho diterima. Jika thitung $\geq \mathrm{t}$ tabel, maka $\mathrm{Ha}$ diterima dan Ho ditolak.

\section{METODE PENELITIAN}

\section{Tempat dan Waktu Penelitian}

Penelitian ini dilaksanakan selama 1 bulan mulai tanggal 4 Januari sampai 2

Februari 2016 di SMA Negeri 1 SaktiKecamatan Kota Bakti, Kabupaten Pidie.

\section{Instrumen Penelitian}

Dalam penelitian ini digunakan sejumlah instrumen yang digunakan sebagai alat untuk mengumpulkan data yang diperlukan yang semuanya dikembangkan sendiri oleh peneliti. Jenis-jenis instrumen yang dikembangkan meliputi Rencana Pelaksanaan Pembelajaran (RPP), Lembar Kerja Siswa (LKS), perangkat tes, dan skala sikap. Instrumen dalam penelitian ini digunakan untuk mengetahui:

1. Hasil belajar siswa; dengan menggunakan paper dan pensil test bentuk objektif tes dengan jumlah 60 soal. Soal tersebut dikembangkan sendiri dan telah diuji validitas oleh para ahli, uji tingkat kesukaran, daya beda dan reabilitas sehingga instrumen tes siap digunakan.

2. Tingkat kemampuan berfikir kritis; dengan menggunakan paper dan pensil test bentuk objektif tes dengan jumlah20 soal. Soal tersebut dikembangkan sendiri dan telah diuji validitas oleh para ahli, uji tingkat kesukaran, daya beda dan reabilitas sehingga instrumen tes siap digunakan.

3. Sikap siswa; skala sikap dimaksudkan untuk mengetahui informasi atau tanggapan siswa terhadap proses pembelajaran biologi pada konsep sistem pencernaan manusia dengan strategipembelajaran model jigsaw. Skala sikap yang dikembangkan merupakan skala "Likert" dengan empat kategori jawaban yaitu Sangat Setuju (SS), Setuju (S), Ragu-Ragu (R), dan Tidak Setuju (TS).

\section{Jenis Penelitian}

Jenis penelitian ini adalah penelitian eksperimen (experimental research)dan metode yang digunakan adalah metode kuantitatif yang akan dilakukan dengan mengadakan pretes dan postes untuk memperoleh data skor tes siswa sebelum dan sesudah pembelajaran.

Desain yang digunakan dalam penelitian ini adalah pretest-postest control group design (Arikunto, 2010).

Tabel 1. Desain Eksperimen

\begin{tabular}{|l|l|l|l|l|}
\hline Sampel & Kelompok & Pretes & $\begin{array}{l}\text { Perlaku } \\
\text { an }\end{array}$ & Postes \\
\hline Acak & A(Eksperimen) & $\mathrm{O}$ & $\mathrm{X} 1$ & $\mathrm{O}$ \\
\hline Acak & $\mathrm{B}$ (Kontrol) & $\mathrm{O}$ & $\mathrm{X} 2$ & $\mathrm{O}$ \\
\hline
\end{tabular}

(Arikunto, 2010) Ket. :

$\mathrm{X} 1=$ Pembelajaran Sistem Pencernaan dengan Model Jigsaw

$\mathrm{X} 2=$ Pembelajaran Sistem Pencernaan dengan Model Konvensional

$\mathrm{O}=$ Tes hasil Belajar

Desain strategi pembelajaran tipe pembelajaran yang menganut prinsip-prinsip pembelajaran kooperatif tipe jigsaw(Aronson, et al., 1997; Gonzalez, et al., 1983; Slavin, 1990).

\section{Populasi dan Sampel Penelitian}

Populasi dalam penelitian ini adalah keseluruhan dari siswa kelas XI yang berjumlah sebanyak 176 siswa, yang terbagi dalam 5 (lima) kelas. Sampel dibagi menjadi dua kelompok yaitu kelompok eksperimen dan kelompok kontrol. Penentuan kelompok eksperimen dan kelompok kontrol diawali dengan melakukan pretest pada semua kelas untuk mengetahui kemampuan awal siswa.

\section{Analisis Data}

Data yang dikumpulkan berupa hasil pretest dan postest ditabulasi dalam bentuk sistem1,0 kemudian dianalisis, dicari skor ratarata jigsaw yang diterapkan dalam penelitian ini merupakan suatu desain rancangan dalam menginterpretasikan perolehan gain masingmasing siswa, maka dilakukan normalisasi gain dengan menggunakan rumus dari Hake (Cheng, et al. 2004) sebagai berikut: Gain, 
dengan cara skor postest dikurangi skor pretest. Untuk menghindari kesalahan postest tersebut selanjutnya dihitung skor kelas eksperimen. Dari data skor pretest dan pretest dan postest pada kelas kontrol dan

$$
N-\text { gain }=\frac{\text { Skor Postest }- \text { Skor Pretest }}{\text { Skor Maks }- \text { Skor Pretest }} \times 100
$$

Dengan kategori perolehan N-Gain: Tinggi : $\mathrm{N}-$ Gain $>70$

Sedang $\quad: 30 \leq \mathrm{N}$-Gain $\leq 70$

Rendah : N-Gain < 30

Skor rata-rata N-Gain antara kelas kontrol dan kelas eksperimen digunakan sebagai data untuk membandingkan hasil belajar siswa. Pengujian perbedaan rata-rata $\mathrm{N}$-Gain diuji dengan menggunakan uji-t, jenis uji-t yang digunakan adalah Independent Sample Test, dengan menggunakan rumus sebagai berikut:

$$
t=\frac{x_{1}-x_{2}}{\sqrt{\left(\frac{\sum x^{2}+\sum y^{2}}{n_{1}+n_{2}-2}\right)\left(\frac{1}{n_{1}}+\frac{1}{n_{2}}\right)}}
$$

Keterangan:

$\mathrm{X} 1=$ rata-rata beda antara pretes dan postes siswa yang dibelajarkan dengan metode kooperatif jigsaw

$\mathrm{X} 2=$ rata-rata beda antara pretes dan postes siswa yang dibelajarkan dengan pembelajaran konvensional

$\mathrm{n} 1=$ Banyaknya siswa yang dibelajarkan dengan metode kooperatif jigsaw

$\mathrm{n} 2=$ Banyaknya siswa yang dibelajarkan dengan pembelajaran konvensional

Pada materi sistem pencernaan makanan pada manusia adalah dengan menggunakan data pengetahuan awal siswa. Hasil analisis kemampuan dan pengetahuan awal siswa menunjukkan tidak ada perbedaan yang signifikan antara kelas eksperimen dan kelas kontrol.

Hasil analisis menunjukkan bahwa siswa kelas eksperimen dan siswa kelas kontrol memiliki kemampuan dan pengetahuan awal yang sama, dalam hasil belajar dan kemampuan berfikir kritis siswa pada materi sistem pencernaan makanan pada manusia.

Peningkatan hasil belajar antara kelas eksperimen dan kelas kontrol dapat dilihatdari nilai $\mathrm{N}$-Gain antara kedua kelas tersebut.

\section{HASIL DAN PEMBAHASAN Perbedaan Hasil Belajar Data yang}

digunakan

untukmengetahui peningkatan hasil belajar siswa Berdasarkan gambar diatas dapat kita lihat bahwa hasil belajar siswa pada materi sistem pencernaan manusia, terjadi peningkatan antara siswa kelas eksperimen dan siswa kelas kontrol, dengan selisih rata- rata skor postes-pretes (N-Gain) kelas eksperimen mencapai 65,91 sedangkan rata- rata kelas kontrol adalah 27. Dari hasil data tersebut menunjukkan bahwa terjadi peningkatan jumlah rata-rata antara $\mathrm{N}$-Gain kelas experimen dan $\mathrm{N}$-Gain kelas kontrol.

Hasil analisis dengan menggunakan Uji T (t-test) Independent sample T-test, diperoleh bahwa nilai thit $(12,13)$ sedangkan

nilai ttabel $(\alpha=0,05)$ yaitu $(1,645)$, jadi dapatberfikir kritis siswa dapat dilihat pada gambar dibawah ini.

Berdasarkan gambar dapat kita lihat bahwa kemampuan berfikir kritis siswa pada materi sistem pencernaan makanan pada manusia, terjadi peningkatan antara siswa kelas eksperimen dan siswa kelas kontrol, dengan selisih rata-rata skor postes-pretes (N-Gain) kelas eksperimen mencapai 67,13 sedangkan rata-rata kelas kontrol adalah 35. Dari hasil data tersebut menunjukkan bahwa terjadi peningkatan jumlah rata-rata antara $\mathrm{N}-$ Gain kelas experimen dan N-Gain kelas kontrol.

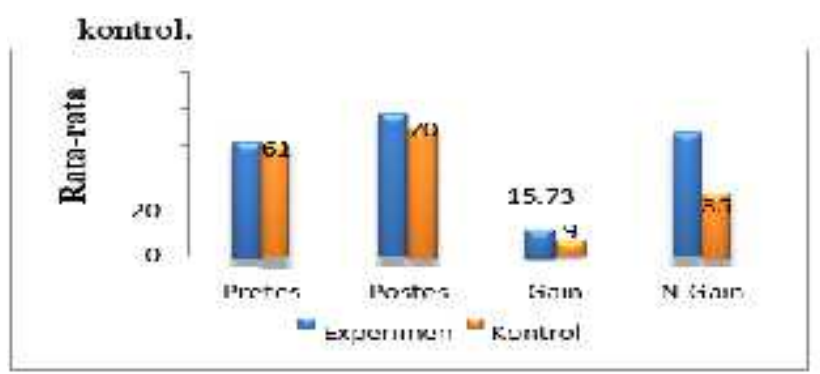

Gambar 2. Grafik Perbandingan Peningkatan Kemampuan Berfikir Kritis Pada Materi "Sistem Pencernaan Pada Manusia" Siswa Kelas Experimen dan Kelas Kontrol.

Hasil analisis dengan menggunakan Uji T (t-test) Independent sample T-test, diperoleh bahwa nilai thit $(7,733)$ sedangkan nilai ttabel $(\alpha$ $=0,05)$ yaitu $(1,645)$, jadi dapat disimpulkan 
bahwa thit $\searrow$ tabel pada $(\alpha=0,05)$,perbedaan hasil belajar pada siswa antara kelas eksperimen dengan kelas kontrol.

\section{Perbedaan Kemampuan Berfikir Kritis}

Untuk mengukur keterampilan berfikir kritis juga dilakukan hal yang sama pada saat mengukur tingkat hasil belajar siswa yaitu dengan cara menghitung selisih antara skor postes dan skor pretes (gain). Peningkatan keterampilan berfikir kritis antara kelas experimen dan kelas kontrol dapat dilihat dari nilai N-Gain antara kedua kelas tersebut. Nilai dari keterampilan maka $\mathrm{Ha}$ diterima, artinya terdapat perbedaan kemampuan berfikir kritis pada siswa antara kelas eksperimen dengan kelas kontrol.

Dalam pelaksanaan penerapan model pembelajaran kooperatif jigsaw pada materi sistem pencernaan makanan pada manusia, peneliti menemukan hasil yang sangat signifikan, artinya model pembelajaran jigsaw ini mampu meningkatkan hasil belajar dan keterampilan berfikir kritis siswa dibandingkan dengan siswa yang diajarkan dengan model pembelajaran konvensional. Selain itu peneliti juga menemukan siswa yang diajarkan dengan model pembelajaran koopertif jigsaw lebih aktif, mampu bekerjasama dengan baik dalam kelompok, serta memiliki semangat dalam belajar. Hasil temuan ini didukung oleh beberapa peneliti yang telah melakukan penelitian mengenai model pembelajaran kooperatif jigsaw seperti penelitian yang dilakukan oleh Jannah (2009) melalui penerapan pembelajaran kooperatif Jigsaw dapat meningkatkan motivasi belajar, hasil penelitian menunjukkan rata-rata indikator motivasi belajar siswa dalam pembelajaran biologi pada siklus I adalah $70,42 \%$ dan pada siklus II adalah 82,92\%. Dari siklus I ke siklus II meningkat $12,5 \%$.

Handayani dan Sapir (2009) juga melakukan penelitian dengan menggunakan model yang sama. Hasil penelitian menunjukkan bahwa, hasil belajar yang diamati terdiri dari tiga aspek, yaitu kognitif, afektif dan psikomotorik. Secara keseluruhan hasil belajar siswa kelas XI IPS1 SMA Negeri 2 Malang dapat ditingkatkan melalui pembelajaran berbasis masalah dan pembelajaran kooperatif tipe Jigsaw. Hal ini dapat dilihat bahwa ketiga aspek dalam hasil belajar mengalami peningkatan.

Nur (2005) menjelaskan tentang kelebihan model pembelajaran koopertif tipe jigsaw adalah: (1) Siswa lebih berkonsentrasi pada proses pembelajaran karena materi yang ditugaskan terfokus, (2) Siswa tidak terlalu menggantungkan diri pada guru, tetapi dapat menambah kepercayaan kemampuan berfikir sendiri, menemukan informasi dari berbagai sumber, dan belajar dari siswa yang lain, (3) Siswa dapat mengembangkan kemampuan mengungkapkan ide atau gagasan dengan katakata secara verbal dan membandingkannya dengan ide-ide siswa lain, (4) Dapat membantu siswa untuk lebih peduli dengan siswa lain dan menyadari akan segala keterbatasannya serta dapat menerima segala perbedaan, dan (5) Dapat membantu memberdayakan setiap siswa untuk lebih bertanggung jawab dalambelajar.

\section{KESIMPULAN}

Berdasarkan hasil penelitian dapat disimpulkan:

1. Terdapat perbedaan hasil belajar siswa yang diajarkan dengan model pembelajaran kooperatif jigsaw dengan siswa yang diajarkan dengan model pembelajaran konvensional.

2. Terdapat perbedaan keterampilan berfikir kritis pada siswa yang diajarkan dengan model pembelajaran kooperatif jigsaw dengan siswa yang diajarkan dengan model pembelajaran konvensional.

3. Penerapan model pembelajaran kooperatif jigsaw dapat meningkatkan hasil belajar dan keterampilan berfikir kritis siswa pada materi sistem pencernaan makanan.

\section{DAFTAR PUSTAKA}

Achmad, A. 2007. Memahami Berpikir Kritis. Tersedia pada: http://www.muhfahroyin.blogger.co mDiakses tanggal:15 Agustus 2010.

Amali. 2000. Pendekatan Dalam Proses Belajar Mengajar. Bandung:Remaja Rosdakarya.

Anderson, L.W\& Krathwohl, D.R., 2001. A Taxonomy for Learning Teaching and Assessing. A Revision of Bloom's Taxonomy of Educational Objectives.New York: Addison Wesley Longman, Inc.

Arend,R.I. 2001. Classroom Instruction and Management. New York USA:Mc Graw Hill. Arikunto, S. 2010.Prosedur Penelitian Suatu Pendekatan Praktek. Edisi Revisi VI. Jakarta: Rineka Cipta. 
Aronson, E., \& Patnoe, S. 1997. The jigsaw classroom: Building cooperation in the classroom. New York: Longman.

Bani. 2004. Berbagai Pendekatan DalamPembelajaran. Jakarta:Bina Aksara.

Budiningarti. $1998 . \quad$ Belajar danPembelajaran. Jakarta:Rineka Cipta. Cheng, K. K., Thacker, B. A., \& Cardenas,

Enchances Students Learning of Physics Concepts in An Introductory Physics Course. American Journal of Physics, 72 (11):1447-1453.

Ennis, R.H. 2000. Goals for A Critical Thinking Curriculum. In A L. Costa (ed). Developing Minds: A Resource Book for Teacher Thinking.Alexandria:Assosiat

ion for Supervisor and CurriculumDevelopment (ASCD).

Evelyn, C. Pearce. 2009. Anatomi dan Fisiologi Untuk Para Medis. Jakarta:PT. Gramedia Pustaka Utama.

Gonzalez, A., \& Guerrero, M. (1983).Jigsaw teacher's handbook. Hollister, CA: Hollister Unified School District.

Gonzales, P. 2009. Highlights From TIMSS 2007:Mathematics and Science Achievement of U.S. Fourthand Eighth-Grade Student in an International

Context.Washington:National Center for Education Statistics. Tersedia pada:http://nces.ed.gov/pubs2009/20090

01.pdf. Diakses pada tanggal 5 Juni 2012.

Handayani, S. dan Sapir. 2009. Efektifitas Penerapan Model Pembelajaran Berbasis Masalah (Problem Based Learning) dan Pembelajaran Kooperatif (Cooperative Learning) Tipe Jigsaw untuk Meningkatkan Aktivitas Belajar, Hasil Belajar dan Respon Belajar Siswa pada Mata Pelajaran Ekonomi di SMA Negeri 2

Malang. JPE Volume-2. Tersedia pada: http://carapedia.com/model_pembela jaran_jigsaw_info587.html,diakses pada tanggal:14 September2012.
Ibrahim,

M. 2000.

PembelajaranKooperatif.

Surabaya:Unesa Press.

Lie, Anita. 2008.

CooperatifLearning.Jakarta:PT Grasindo

Liliasari. 2009. Berfikir Kritis dalam Pembelajaran Sains Kimia Menuju Profesionalitas Guru. Bandung:Program Studi Pendidikan IPA Sekolah Pascasarjana UPI.

Martin, M.O. \& Mullis, I.V.S.,1999.

International Report: Finding from IEA's Repeat of the Third International Mathematics and Science Study at the Eight Grade (TIMSS).Boston: ISC. Diakses pada tanggal 2 mei 2012.

Martin, M.O., Beaton, A.E., Mullis, I.V.S., Gonzalez, E.J., Smith, T.A., \& Kelly, D.L. 2003. Science Achievement in the Middle School Years: IEA's Third International Mathematics and Science Study (TIMSS). Chestnut Hill, MA: Boston College.Diakses pada tanggal 2 Agustus 2012.

Muhfahroyin. 2009. Memberdayakan Keterampilan Berpikir Kritis. Tersedia pada: http://www.muhfahroyin.blogger.com Diakses pada tanggal:30 September2012.

Nurhadi. 2003. Pembelajaran Kontekstual dan Penerapannya dalam KBK. Malang: Universitas Negeri Malang

Nur, M. 2005. Pembelajaran Kooperatif.Surabaya:Pusat Sains dan MatematikaSekolah UNESA.

Pendi, S. 2002. Pembelajaran Fisika Dasar II Pokok Bahasan Arus Listrik dan Rangkaian Listrik Arus Searah Dengan Menggunakan Model Pembelajaran Kooperatif Tipe Jigsaw. Surabaya:Tesis Magister Pendidikan, UNESA.

Pratiwi, D.A.(2005).Biologi Untuk SMA Kelas XI. Jakarta:Penerbit Erlangga.

Santoso, S. 2007. Menguasai Statistik di Era Informasi dengan SPSS 15. Jakarta:PT. Elek Media Komputindo. 